Hugoye: Journal of Syriac Studies, Vol. 10, 33-52

(C) 2007 by Beth Mardutho: The Syriac Institute and Gorgias Press

\title{
FORTY YEARS OF SYRIAC COMPUTING
}

\author{
GEORGE A. KirAZ \\ BETH MARDUTHO: THE SYRIAC INSTITUTE
}

\begin{abstract}
The term "Syriac Computing" was coined in 1992 and took shape in 1995 when the First International Forum on Syriac Computing was beld in conjunction with the Second Syriac Symposium in Washington, DC. The term was applied to computer-related activities and projects which support Syriac studies. Syriac computing, however, began much earlier though on a small scale. On the $10^{\text {th }}$ anniversary of Hugoye and the $15^{\text {th }}$ anniversary of its parent, Beth Mardutho, whose contributions to Syriac computing are well known, this paper aims to outline the history of Syriac computing and offer some considerations for the future.
\end{abstract}

\section{COMPUTATIONAL LEXICOGRAPHY}

[1] The first project that is known to me which employed computer systems for the study of Syriac falls within the domain of computational lexicography, and is only known through oral tradition. Stanislav Segert, former Professor at University of California, Los Angeles (UCLA) from whom I learned this in the mid 1980s, heard that someone at UCLA had encoded Brockelmann's Lexicon Syriacum on a mainframe computer system back in the 1960s. He attempted to trace down the data during his tenure, but was unable to find anything. One can speculate that at minimum these data contained a transcription of the Syriac lexemes in the Lexicon, maybe with Latin correspondences as well. It is unknown if more linguistic data 
tagging was applied, such as morphological information. The data must have been entered using punch cards. Nothing is known about the intention of the project; it may have been simply a study aid.

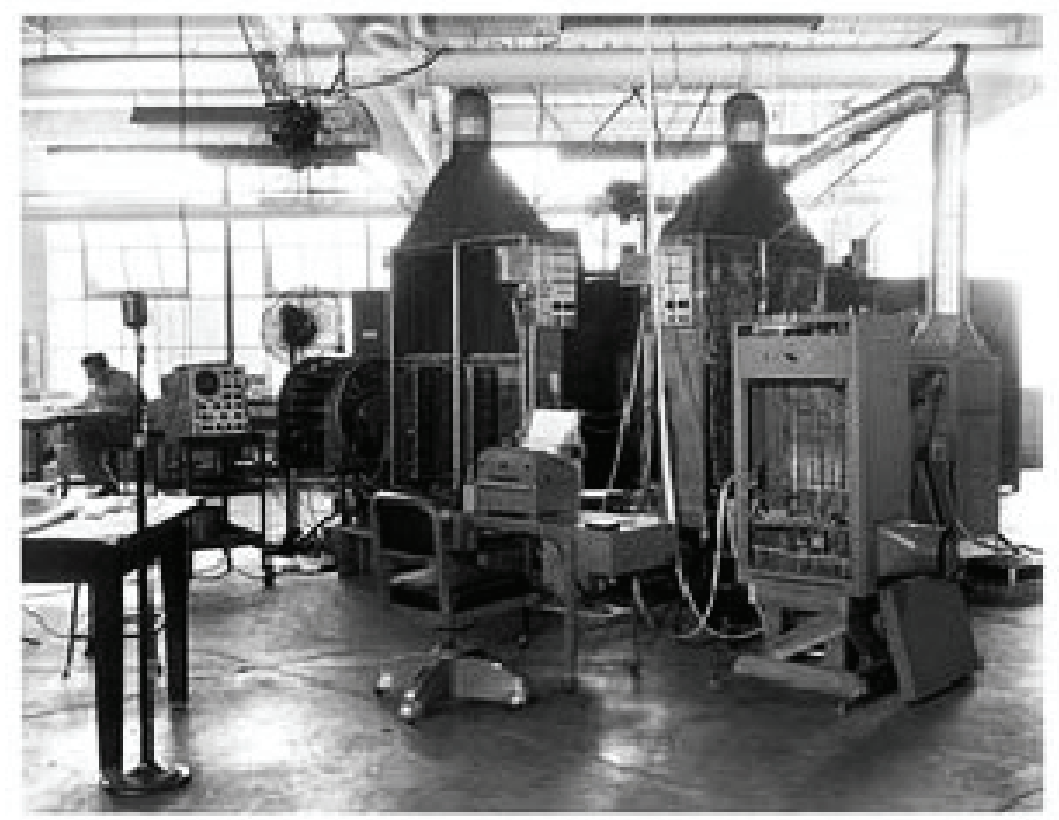

Figure 1. Computer system similar to the one used at UCLA in the 1960s.

Later lexicographical projects aimed at the generation of concordances, primarily to biblical texts. These are discussed below in chronological order.

\section{The Göttingen Project}

[3] In 1970, an ambitious project began in Göttingen to publish concordances to Biblical texts. The project was called Der Göttinger Syrischen Konkordanz, and used Fortran IV as its programming language. ${ }^{1}$ The resulting concordances were subsequently published. ${ }^{2}$

1 The description given here is based on M. Zumpe, Technische Aspekte der Göttingen Syrischen Konkordan₹. (Deutsche Arbeitsgemeinschaft Vorderer Orient, September 2001).

2 Werner Strothmann, Konkordanz zum Syrischen Psalter (1976); Werner Strothmann, Konkordanz, zur Syrischen Bible: Der Pentateuch (1986), Der Propheten (1984). 
The data model of the Göttingen project was a simple one. Tables were saved in flat files, where each line in a file represented a record. Fields in each record were fixed-length. Entering data was a challenge in its own right. Someone who must have known Syriac, or at least the Syriac alphabet, transcribed data on data cards. The data was then entered, by someone who did not have to know Syriac, using a traditional keyboard used to generate a punch card. The punch card was then fed to an IBM mainframe computer. Syriac text was entered using simple transcription (one-to-one mapping from Syriac letters to ASCII).

\section{The Way International Project}

Also in 1970, and probably unknown to the Syriac studies community at the time, The Way International, a "nondenominational, nonsectarian Biblical research, teaching and fellowship ministry" (as it describes itself on its web site), began an ambitious project to create a Syriac concordance to the Syriac New Testament. The Way was motivated by George Lamsa's unfounded claims that the Peshitta is superior to the Greek New Testament and represents an original Aramaic version of the New Testament. ${ }^{3}$ During a period of 15 years, The Way managed to encode the entire Syriac New Testament, with a comprehensive lexical database. The concordance ${ }^{4}$ that came out of the project was a mere word list, despite the fact that the data model was sufficient to create a concordance as detailed as the one produced later by Kiraz. ${ }^{5}$ The Way managed to publish other useful tools from the project: an edition of the New Testament in the Estrangelo script, $^{6}$ an inter-linear Syriac-English edition of the Peshitta New Testament, ${ }^{7}$ and an English-Syriac index..$^{8}$ At the time, The Way initially

3 George A. Lamsa, The Holy Bible From Ancient Eastern Manuscripts, Containing the Old and New Testaments Translated from the Peshitta, The Authorized Bible of the Church of the East (Nashville: Holman Bible Publishers, 1933, 22nd printing 1981); the NT was reprinted by Harper \& Row, n.d. For Lamsa's claims, see George M. Lamsa, New Testament Origin (Aramaic Bible Center, 1976).

4 The Way International, The Concordance to the Peshitta Version of the Aramaic New Testament (Ohio: American Christian Press, 1985).

${ }^{5}$ George Kiraz, A Computer Generated Concordance to the Syriac New Testament, volumes 1-6 (Brill, 1993).

${ }^{6}$ The Way International, The Aramaic New Testament (Ohio: American Christian Press, 1983).

7 The Way International Research Team, Aramaic-English Interlinear New Testament, vol. 1 Matthew-John 1988, vol. 2 Acts-Philemon 1988, vol. 3 HebrewsRevelation (American Christian Press, 1989).

8 The Way International, English Dictionary Supplement to the Concordance to the Peshitta Version of the Aramaic New Testament (American Christian Press, 1985). 
made these publications available to individuals who were not members of their organization. I managed to obtain a set!

The data model employed here was based on a relational database. The data were later made available through the Ancient Biblical Manuscript Center (Claremont, CA). The Center received this data on a single magnetic reel-to-reel tape containing twelve data files. The format was created on an IBM System 38 computer. The files were downloaded onto sixteen 364K, 5 $1 / 4$ " floppy disks in a PC environment with the help of the Academic Computer Center at the Claremont Graduate School. Each record type was represented in a flat file, one record per line. Fields were fixed-length. The data was later utilized by Kiraz in the SEDRA database project (see below).

\section{Borbone / The Peshitta Institute}

During the 1980s, Pier Giorgio Borbone developed a computational system with which he produced a number of concordances to Biblical texts. Description of this system can be found in various papers. ${ }^{9}$ The Borbone system has been developed further and is currently being used for the generation of the Leiden Peshitta concordance, of which one volume has already appeared. ${ }^{10}$

\section{Kiraz's SEDRA Database}

The initial work of George Kiraz's lexical work goes back to 1984 when he began encoding existing lexica in relational databases. The first attempt was to encode an Arabic-Syriac version of Costaz's dictionary. ${ }^{11}$ Only the letters Olaph-Dolath were entered at the time. In a second attempt during 1990, Kiraz tried getting an international group of volunteers to encode

9 P. Borbone, 'L'uso dell'elaboratore elettoronico per lo studio della Pešit?a', Henoch 9 (1987), pp. 55-96; P. Borbone, 'Un programma per l'elaborazione di testi siriaci e un progetto di redazione di concordanze della peshitta', in R. Lavenant (ed.), V Symposium Syriacum 1988, Orientalia Christiana Analecta 236 (1990), pp. 439-50; P. Borbone and F. Mandracci, 'Another way to analyze Syriac texts, a simple powerful tool to draw up Syriac computer aided concordances', in Proceedings of the Second International Colloquium, Bible and Computers: Methods Tools, Results, Travaux de Linguistique Quantitative 43 (1989), pp. 135-45.

${ }^{10}$ The Peshitta Institute, The Old Testament Concordance According to the Peshitta Version, Part V Concordance (Leiden: E. J. Brill, 1997).

${ }^{11}$ For another unfinished computational work on Arabic-Syriac dictionaries, see George Kiraz and Daniel Ponsford, 'Automatic Compilation of Semitic Lexica', in Proceedings of the 4th International Conference and Exbibition on Multi-Lingual Computing (1994); George Kiraz and Daniel Ponsford, 'The Arabic-Syriac/SyriacArabic Dictionary Project: Report II', in G. Kiraz (ed.), SyrCOM-95: Proceedings of the First International Forum on Syriac Computing (1995). 
Margoliouth's Syriac-English dictionary through Alaph Beth Computer Systems. The system was called in Syriac sedra "array" as databases are considered arrays of data. The acronym SEDRA at the time stood for "Syriac Electronic Data Research Archive."12 In this case too, very little was achieved. On March 2, 1988, Kiraz signed an agreement with the Ancient Biblical and Manuscript Center and incorporated its data into SEDRA. The system was used to publish a detailed concordance to the Syriac New Testament, and a pedagogical word list to assist students in learning New Testament Syriac.13 Recently, Logos Research Systems incorporated SEDRA in its Scholar's Library. ${ }^{14}$ In addition, a team of international scholars are currently using SEDRA to generate an interlinear to the Syriac New Testament. SEDRA is available for download from the Beth Mardutho web site (http://www.bethmardutho.org). A number of online tools have already been implemented using SEDRA. ${ }^{15}$

SEDRA went through three incarnations. SEDRA I (1989) derived from the database provided by The Way International through the Ancient Biblical and Manuscript Center. As flat files were not necessarily efficient for modeling databases, the relational database was converted for use in db_VISTA, ${ }^{16}$ a database management system that provided a programmable interface in the $\mathrm{C}$ programming language for writing database applications. In the next incarnation, SEDRA II (1990), additional tables and fields necessary for the generation of Kiraz's Concordance were added. Moreover, the entire text of the New Testament was vocalized and pointed, punctuation marks were added, and the text was normalized to represent the BFBS edition of the Syriac New Testament, ${ }^{17}$ as the text used by The

${ }^{12}$ George A. Kiraz, ri.so The Syriac Electronic Data Research Archive (SEDRA) (leaflet), pp. 1-3.

${ }^{13}$ George A. Kiraz, 'Automatic concordance generation of Syriac texts', in R. Lavenant (ed.), VI Symposium Syriacum 1992, Orientalia Christiana Analecta 247 (1994), pp. 461-75; G. Kiraz, A Computer-Generated Concordance to the Syriac New Testament, 6 vols. 106. (Leiden: E. J. Brill, 1993); G. Kiraz, Lexical Tools to the Syriac New Testament (Sheffield: Sheffield Academic Press, 1994; Piscataway: Gorgias Press, 2002).

${ }^{14}$ Logos Research Systems, Scholar's Library Silver Editon: A professional-level library of texts and tools for serious Bible Study using Greek, Hebrew, and English resources, Logos Bible Software Series X (2004).

${ }^{15}$ Examples are Syriac Dictionary, a useful tool by Abed Daoud (available from http://www.bethmardutho.org), and a similar on-line tool at http://www. peshitta.org.

${ }^{16}$ Raima Corporation, db_VISTA III ${ }^{\mathrm{TM}}$, Version 3.10 (Bellevue, WA: 1989).

${ }^{17}$ British and Foreign Bible Society, The New Testament in Syriac (London: 1919 and subsequent editions). 
Way was based on other manuscripts, primarily from the British Museum. ${ }^{18}$ To accomplish the vocalization and pointing process, a program was written that skipped over words which had been already vocalized.

Initial bgdkpt letters were always marked with a qushshaya point; an algorithm was written to convert the qushshaya into rukkakha if the preceding word, if any, ended in a vowel and was not followed by a punctuation mark. The dot on the feminine object pronominal suffix was not included in the pointing, and is to be added by another algorithm based on the existing morphological data. The same applies to seyame. Many of the online tools that generated NT texts from downloading SEDRA ignored these features and hence produced texts without seyame and the feminine marker.

The next incarnation of the project was SEDRA III (1991). The first change was the move from a relational model to a network model where ordered, one-to-many parent-child relations provided ease for concordance generation. The technical aspects of this model have been described in detail elsewhere. ${ }^{19}$ SEDRA III contains 2,050 roots, 3,559 Lexemes, 31,079 word forms and 6,337 English meanings (particular to the context of the New Testament).

\section{Brigham Young University's Bar Bahlul Project}

[12] In early 1998, ISPART (then CPART) commissioned G. Kiraz to implement a linguistic database of the Syriac language that can be used as a tool to implement search engines of Syriac texts. Central to the creation of a searchable Syriac text was an electronic lexicon compounded with a morphological generator. As Syriac is a highly inflected language, it is not possible to enumerate all of the Syriac words that may occur in texts. Kiraz proposed that a linguistically motivated lexicon be created, accompanied with a morphological generator that would create all, or as many as possible, inflected Syriac words, and named the project after the famous $10^{\text {th }}$ century lexicographer Bar Bahlul.

The electronic lexicon was built in Access Format, and populated with roots and lexemes with many morphological attributes. The database contains abstract information from which a fuller lexicon can be generated using a morphological generator. The morphological generator is expressed in ASCII files according to a special format. In addition to deriving all verbal forms for each root based on information provided in the electronic

${ }^{18}$ For a list of the manuscripts used, see The Aramaic New Testament, Estrangelo Script (1983) p. x.

19 George Kiraz, 'Automatic Concordance Generation', in René Lavenant (ed.), VI Symposium Syriacum 1992, Orientalia Christiana Analecta 247, pp. 461-475. 
lexicon, the morphological generator creates forms with object pronominal suffixes, possessive suffixes, and prefixes. ${ }^{20}$

\section{The Comprehensive Aramaic Lexicon}

[14] In the 1980s, The Comprehensive Aramaic Project was born under the direction of Stephen Kaufman. The project is ambitious and aims at covering all dialects of ancient Aramaic. This is probably the first project involving Syriac wherein the lexical aspects of the project are primary, and concordance generation is secondary (i.e., concordance helps in compiling a lexicon).

Various publications dealing with Aramaic dialects other than Syriac have already come out. ${ }^{21}$ The publication of a concordance to the Old Syriac Gospels has just been published. ${ }^{22}$ More information on CAL can be found on the project's web site at http://cal1.cn.huc.edu.

\section{Word Processing ANd Desktop Publishing}

[16] Until the 1970s and even the early 1980s, publishing Syriac texts used traditional methods such as movable type, and machine-set types (e.g., the Syriac types produced in the 1920s by American Linotype, and the Estrangelo type produced by the British Monotype Corporation in 1954).23

With the advancement of computers, institutions began looking for ways to use computer technology to print Syriac texts. The first publications that employed computer technology for the production of the text were the concordances of the Göttinger Syrischen Konkordanz project mentioned above. The text was produced on a plotter, an output device that draws pictures and drawings using one or more pens, usually used by the engineering community for architectural drawings. This system was not used, to the best of my knowledge, beyond the project's publications.

Another early project, one that made use of a more advanced technology, was initiated by the Assyrian Church of the East in the early 1980s. The Church's Literary Committee commissioned Purdy and

20 This approach departs radically from the more ubiquitous approach of using finite-state technology for morphological analysis and generation. It was used because of its ease and the lack of a finite-state engine. For a finite-state approach to Semitic morphology, see George Anton Kiraz, Computational Nonlinear Morphology: With Emphasis on Semitic Languages (Cambridge: Cambridge University Press, 2001).

${ }^{21}$ See http://cal1.cn.huc.edu for a list of publications.

22 J. Lund, The Old Syriac Gospel of the Distinct Evangelists, A Key-Word-InContext Concordance, volumes 1-3 (Piscataway: Gorgias Press, 2004).

${ }^{23}$ For a detailed history, see J. F. Coakley, Typography of Syriac: A Historical Catalogue of Printing Type, 1537-1958 (Oak Knoll Press, 2006). 
Macintosh to produce a high-resolution digital phototypesetting system. The term "digital" here needs to be qualified. The device, and the software that was implemented on the device, were indeed digital (i.e., a specialpurpose computer). The actual output of the device, however, was a photographic one. This was advantageous at the time as photographic type produced better quality than digital type. The device's photographic results were of the highest quality, at a resolution of up to 2602 elements per inch. In addition to Syriac, the device handled English and Arabic, catering for the need of the Church. The Syriac fonts were designed by the Church's team and included one Estrangelo and one East Syriac type. The device was announced in 1985. The Church produced a beautiful lectionary using this system and a number of publications. Such devices proved to be quite expensive, which was a factor in their limited distribution. The general user had to wait until the popularization of personal computers, and the availability of Syriac digital types for these platforms.

\section{The DOS Era}

[19] With the release of the IBM Personal Computer in the early 1980s, the age of personal computing really began. Individuals were able now to obtain such machines. By the mid 1980s, PCs were competing with the Apple Macintosh system, and to a lesser extent with the Atari system. This period witnessed a number of attempts by various individuals to implement Syriac fonts for various platforms. It is difficult here to give an account of all such efforts for the lack of documentation. Instead, I shall outline here my personal experience in developing Syriac fonts, mentioning the work of others when possible.

I began looking into the problem of Syriac fonts and word processing in 1984. My first attempts to represent a Syriac letter digitally revolved around hard-coding a representation of each glyph manually. I began by drawing an 8-column grid on a piece of paper. The choice of eight was because a byte, the unit of storing information in computers, consists of eight binary bits. I then drew the letter in the grid. For each row, a filled cell was assigned 1 and an empty was assigned 0 , and these were then put together to form an 8-bit byte as shown in Figure 2. The collection of bytes (one per row) were then represented in the $C$ programming language as an array; e.g., the letter Beth was represented as follows:

int Beth $[14]=\{0 \mathrm{x} 00,0 \mathrm{x} 00,0 \mathrm{x} 3 \mathrm{E}, 0 \mathrm{x} 41,0 \mathrm{x} 01,0 \mathrm{x} 0 \mathrm{E}, 0 \mathrm{x} 00,0 \mathrm{x} 00\}$; 




Figure 2. Crude binary representation of beth. Binary numbers shown in black and red; hex numbers are shown in blue.

This crude attempt produced ugly output. The lack of a word processor that would communicate with such a representation of fonts made the result useless.

In 1985, I came across two products from a Colorado-based company called Data Transforms Inc.: Fontrix ${ }^{\mathrm{TM}}$ and Printrix ${ }^{\mathrm{TM}}$. The former product allowed the user to type text on a graphic screen using bitmap fonts. The input method allowed left-to-right as well as right-to-left writing. What made it interesting is that it came with a font editor that allowed the user to create new fonts. The Printrix product allowed the user to print larger documents avoiding the graphical screen. Fontrix and Printrix had a number of serious limitations. The font editor did not allow scanned images, forcing one to rely on manually drawn glyphs. Marks could not be placed above or below base glyphs. As the input was drawn on a graphical screen, one could not edit the text without having to delete it first. There was no text wrapping either. Despite these deficiencies, I produced a few crude fonts for private use as shown in Figure 3. Independently, Touma Issa produced a Syriac font in Fontrix with the help of his father Corepiscopos Butros Touma, and used it to print church banners in 1986. 


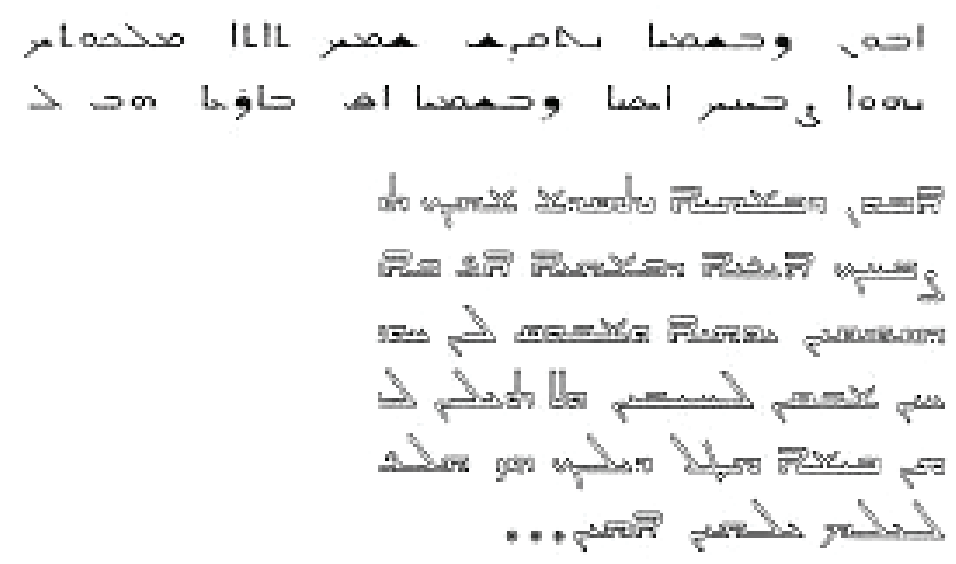

Figure 3. Crude Fontrix and Printrix fonts (1985).

In 1986 Gamma Productions of California issued version 3.0 of its multi-lingual word processor Multi-Lingual Scholar ${ }^{\mathrm{TM}}$ (MLS). This software was truly multi-lingual in the sense that if the user was typing in a particular language, the typographical rules of that language applied. Indeed, it remained for PC-based systems the only unchallenged multi-lingual word processor until very recently when Microsoft released its multi-lingual operating system Windows 2000. MLS came with Latin, Cyrillic, Greek, Hebrew, and Arabic, with the possibility of adding other languages. Its importance to Syriac resided in the fact that MLS came with a font editor that allowed the user to create new fonts, indeed, new languages. The font editor was able to read scanned images; hence, one was able to design highquality fonts based on books published from metal types. The word processor worked bi-directionally. One was able to place up to three marks above and below a letter (ample for Syriac), and the font allowed for twenty such marks.

[23] Alaph Beth Computer Systems, a company that I founded in 1986 and was operational until the early 1990s, produced a suite of Syriac fonts for MLS. Two Estrangelo fonts, one similar to the Monotype design, and the other based on a type originally designed by W. Drugulin of Leipzig ca. 1880; one Serto font modeled after a type whose original design dates back to a type associated with the famous diplomat and printer of Arabic, Savary de Bréves, before 1614; and one East Syriac font, based on a type by 
Drugulin ca. 1880, designed with helpful comments from Mar Emanuel Emanuel of the Church of the East. ${ }^{24}$

MLS used the bitmap font technology; i.e., drawing glyphs by pixels similar to my early crude attempt but using a more sophisticated font editor. This meant that a font was designed for a specific point size; another size would require designing a new font (usually copying the old font and editing it). Additionally, as each printing device had a different resolution (i.e., printed a different number of pixels per inch), each font at each size had to be designed for various printer solutions. 300 dots-per-inch (dpi) laser printers, $240 \mathrm{dpi}$ 24-pin dot matrix printers, and $180 \mathrm{dpi}$ 9-pin dot matrix printers in both draft and quad-density modes.

MLS had a number of shortcomings. Formatting commands had to be typed within the text. No file could be larger than $64 \mathrm{~K}$ bytes, including formatting commands. This meant that a complicated document, such as my Concordance to the Syriac New Testament (1990), could not be more than five or six pages long. The 4,640-page Concordance had to be split into 928 files, but MLS had the ability to link each document to a "previous" and "next" document, creating a chain of documents. (Luckily, I had my concordancegeneration software create and link the 928 files so that with one print command I was able to print the entire text.) While such limitations would be unacceptable to the modern computer user, the user of the 1980s was satisfied to have such a multi-lingual capability, with a high-resolution output.

[26] The MLS Syriac fonts were used in a number of other scholarly publications, but more so amongst the Syriac-speaking communities. Bar Hebraeus Verlag in Holland published over 50 books with these fonts. The fonts appear in journals, wedding invitations, and even tombstones! A screen shot appears in Figure 4.

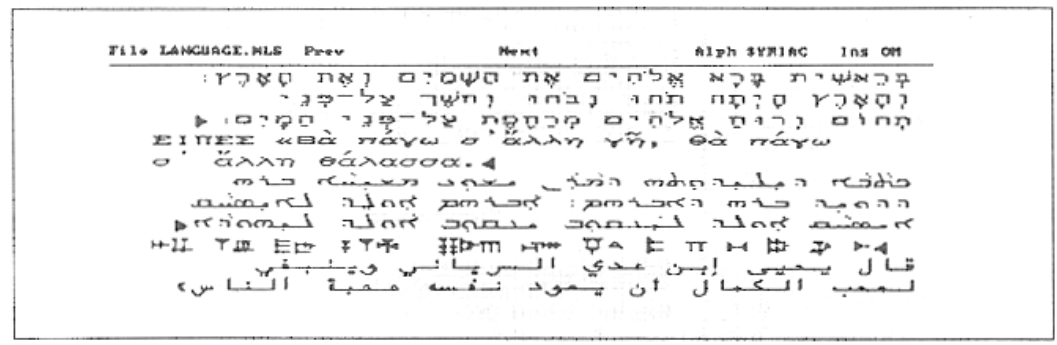

24 These fonts were later redesigned for use in Meltho OpenType suite. They correspond to the following fonts, respectively: Estrangelo Edessa, Estrangelo Nisibin, Serto Jerusalem, and East Syriac Adiabene. 
Figure 4. Screen shot of MLS 3.2 showing Kiraz's Syriac, Arabic and cuneiform fonts, along with Gamma Production's Hebrew and Greek fonts (1986).

In the 1988 Symposium Syriacum held in Louvain, I declared that MLS is "the most sophisticated word processor that has all the requirements needed [for Syriac]". ${ }^{25}$ Bill Gates of Microsoft is also quoted to have said in 1981, "640K ought to be enough for anybody." Syriac desktop systems would continue to advance.

\section{The Windows Age}

[28] During the 1990s, users started shifting from the DOS-based operating system to the more user-friendly Windows operating system. At the time Microsoft had different language-based operating systems. A Middle East version supported right-to-left writing. During this period, a number of fonts were produced by various people. Fonts for the standard Windows operating system were limited as users had to type texts backward, or use a utility program that switched the text for them. Those designed for the Middle East Windows version worked perfectly. In essence, the font designers designed an Arabic font, replacing Arabic glyphs with their corresponding Syriac glyphs. There was one problem that was ingeniously overcome by the font designers: The letters Sodhe and Taw are right-joining in Syriac but their counterparts in Arabic are dual-joining. As the rules of joining letters was hard-coded in the operating system, the fonts used the Arabic ta-marbuta position for Taw, and a similar letter for Sodhe. The font methodology of the time was using TrueType fonts. These were outline fonts rather than bitmaps. The font designer had to define the shape of a glyph in terms of Bezier curves using a user-friendly font tool. One design is good enough for all sizes and resolutions. The computer takes care of figuring out the size of the font. One popular font was suryani2 whose origins I do not know.

During this period numerous other fonts were designed by various people. Listing them gives an indication of the widespread use of computers and web sites: ${ }^{26}$

- Gamma Productions redid my Alaph Beth Computer Systems fonts to be used for their Windows-based tools in 1995.

${ }^{25}$ G. Kiraz, "Computers: Innovation and New Future to Syriac Studies.” René Lavenant, S.J. (ed.), V Symposium Syriacum 1988. Orientalia Christiana Analecta 236, 1990, pp. 451-8.

${ }^{26}$ I am grateful to Nicholas Al-Jeloo who provided me with this list (Email personal communication, November 15, 2001). 
- Steven J. Lundeen of Emerald City Fontworks, Seattle, designed a decorative font in 1997.

- Yakob Ishak Oraha, Europe, designed a collection of East, West and Estrangelo fonts in 1998.

- Tony Khoshaba, Chicago, IL, designed Ishtar Web in 1998.

- James Adair designed an Estrangelo font called SPEdessa based on the Leiden Peshitta edition in 1998.

- Dawod Abed, Germany, designed a Serto font called "Dawod" to be used in his Aramaic Write word processing program in 1998.

- Ashur Cherry of Ontario, Canada, designed 15 East and 4 Estrangelo fonts for the Ashurbanipal software and made them available on the Internet in 1999.

- Nabu Publishing in Australia designed East Syriac fonts in 1999.

- Mesut Tan, Germany, designed four Serto fonts and one Estrangelo font in 2000.

- Michael Davodian, Germany, designed fonts which were then used on Web sites.

- David Chibo and the Assyrian Youth Group of Victoria, Melbourne, Australia, produced fonts in the Assyria's Letters series. These included two East, one Serto, and two Estrangelo fonts.

- International Systems Consultancy, Australia, produced an East Syriac font named Assyrian Web. It was used by the makers of the Farsi-based Parsnegar word processing system.

During this period, Yannis Haralambous designed Sabra, ${ }^{27}$ a collection of outline fonts and macros for use in the TEX typesetting languages. The project was part of a wider activity under the auspices of the ScholarTEX project. The encoded text was processed by TEX-XET, the bidirectional version of TEX. A preprocessor, written as a set of macros and directives, allowed the user to encode texts in a more user-friendly fashion. The Haralambous fonts included all scripts. His Serto script was the first to use fine ligatures based on manuscript tradition (e.g., changing the angle of Gomal depending on if the following letter is Lomad, ${ }^{e} \mathrm{E}$ or otherwise). I am not aware of how many publications made use of this system. I used it to produce my Comparative Edition of the Syriac Gospels.28

By 2000, Microsoft decided to collapse its different language-based operating systems into one, and hence multi-lingual computing took a new

27 Yannis Haralambous, 'Sabra, a Syriac TEX System' in G. Kiraz (ed.), SyrCOM-95: Proceedings of the First International Forum on Syriac Computing (Cambridge: The Syriac Computing Institute, 1995).

${ }^{28}$ G. Kiraz, Comparative Edition of the Syriac Gospels, Aligning the Sinaiticus, Curetonianus, Peshitta and Harklean Versions, 4 vols. (Brill, 1996; Gorgias Press, 2004). 
shape with the release of Windows 2000. Coupled with this, a consortium of companies proposed a new font format called OpenType. These would be TrueType fonts with additional information built into them. Whether a letter is right-joining or dual-joining would now be stored in the font (not hard coded in the operating system). The distance of a diacritical point can be defined per glyph and that also can be saved in the font. Ligatures, kerning and other typographical data can all be part of the font now. The font designer will no longer be at the mercy of the operating system (as long as the operating system renders OpenType technology properly).

Paul Nelson, Sargon Hasso and I embarked on putting specifications for Syriac OpenType fonts, and the results were the fonts in the Meltho font package, available as a free download from http://www.bethmardutho.org. Alas, we have never documented in detail the technical aspects of the Meltho fonts. OpenType technology brought Syriac font design to a new level, and it would be useful to document this not only for practical reasons, but also for historical purposes. In brief, the fonts contain rules that specify the position of each letter, the distance of each mark from each glyph, and many additional rules that fine-tune the appearance of fonts. For instance, a kerning rule will distance a final Nun from a Dolath if the Nun hits the Dolath as depicted in Figure 5. Other rules may elongate the line joining letters. Such fine-tuning rules may be specified using left and right context regular expressions. The rules are usually specified by the user graphically and may be compiled as finite-state machines.

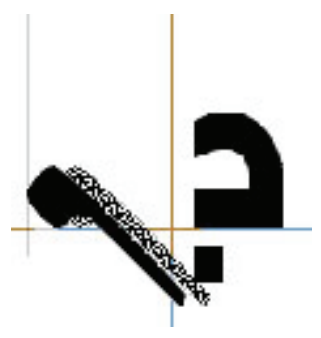

Figure 5. Kerning of Dolath and Nun.

The only other sets of fonts I am aware of that were designed under this methodology were the East Syriac fonts by Dr. Isho Marcus and Rabi Daniel Benjamin. The former has been involved in font design for decades and in fact was instrumental in the Assyrian Church of the East system mentioned above. The latter comes from a family of printing tradition in Iraq. 


\section{STANDARDS}

Since the inception of computer science, standards have emerged to ensure compatibility in platforms and applications. This became more important with the ubiquitous usage of computers world wide. One such standard is Unicode, replacing the old ASCII standard for storing texts in computers.

Windows 2000 dictated that any supported script must be part of the Unicode standard. This led Paul Nelson, Sargon Hasso and I to embark on writing a detailed proposal for the Unicode Consortium. ${ }^{29}$ The proposal was sent to a number of scholars, who also wrote recommendation letters to the Unicode Consortium. ${ }^{30}$ The proposal was submitted to the Unicode Consortium on February 27, 1998 and a unanimous resolution was passed on that day to accept it. Syriac became officially part of Unicode 3.0 in $2000^{31}$ and occupied the 0700-074F slots. The standard defined 14 punctuation marks, 29 letters (the 22 letters, Garshuni letters, CPA Pe, a dotless Dalath/Rish, and a Yudh-He Yahweh ligature), and numerous diacritical marks and points. A new addition was the Syriac Abbreviation mark, a control letter that marks the beginning of an overstrike abbreviation mark.

In 2002, Nicholas Sims-Williams and Michael Everson proposed the addition of six additional Syriac letters for use in Sogdian and Persian, ${ }^{32}$ which were incorporated into Unicode 5.0 in 2007.33 Syriac letters used for Malayalam Garshuni have not yet been proposed..$^{34}$

There are other standards in which Syriac appears. For instance, the language name is now part of ISO 639 which provides codes for all languages. Syriac is assigned to "Sy" in the two-letter codes and "Syr" in the three-letter codes.

\section{THE INTERNET}

In 1992, the World Wide Web was charted, and only a year later, individuals from the Aramaic-speaking world began creating web sites.

29 Paul Nelson, George Kiraz and Sargon Hasso, Proposal to encode Syriac in ISO/IEC 10646 (February 20, 1998), 46 pages. Independently, an earlier proposal was filed by Sargon Hasso and Peter Jasim in 1997.

30 These were Sebastian P. Brock, Mor Julius Y. Çiçek, J. F. Coakley, E. J. Wilson, Luk Van Rompay, Konrad Jenner, and Heleen Murre-van den Berg.

31 The Unicode Consortium, The Unicode Standard, Version 3.0 (2000).

${ }^{32}$ Nicholas Sims-Williams and Michael Everson, Proposal to add six Syriac letters for Sogdian and Persian to the UCS (March 30, 2002).

${ }^{33}$ Julie D. Allen et al. (eds), The Unicode Standard, Version 5.0 (2007).

34 For a description, see Koonammakkal Thoma Kathanar, 'Malayalam Karshon' in The Harp 10 (1997):59-64. 
Giving a detailed history of web sites or listing known ones in chronological order-despite the short history-is not an easy task. Electronic archives of early versions of sites, even those that are still active, no longer exist, and their creators in most cases did not have a reason to keep a record. While this is somewhat harmless, it should alert us to the fact that today's web site may not be there tomorrow. This becomes a serious problem in the case of content-based sites such as the soon-to-becomeavailable eBethArké library. How do we guarantee that digitized forms of unique material (such as manuscripts and archives, as opposed to printed books) will be kept safe for generations to come?

The following is an attempt to list in chronological order the creative web sites that appeared between 1993 and 1996 based primarily on information received from the web site creators themselves.

Firas Jatou, then an electromagnetics undergraduate student at the University of Toronto, is credited with being the first to publish a community web site. He named it Assyria Online and it was hosted at the university server under the URL http://waves.toronto.edu/ jatou (no longer valid) until 1995. It was then moved to http://aina.org/aol where it currently resides. Very soon after, Nineveh Online by Albert Gabriel appeared which was converted from an earlier dialup Bulletin Board System called eBabylon. ${ }^{35}$

In late 1993 or early 1994 (I don't even know now!), The Syriac Computing Institute (the former name of Beth Mardutho) published the first academic site dedicated to Syriac studies on the Web server of the Computer Laboratory of the University of Cambridge. The SyrCOM site, as it was then known, gave information about the Institute and its activities. In 1997, the site was moved to the web server of The Catholic University of America, where later the Institute hosted its Hugoye journal. In 2002, the Institute obtained its own domain name, bethmardutho.org and the site was moved there.

[43] The year 1995 witnessed more intense activities. On Feb 6, 1995, Wilfred Alkhas published the first issue of his Zenda Magazine in the form of an email message, which went out to 12 people in Chicago, San Jose and Sidney. On November 3, 1997, it was hosted on a web site, but continued to be sent as an email until the end of 1999. Zenda Magazine was renamed to Zinda on November 9, 1999 due to a conflict with a Silicon Valley computer game company named Zenda Games. Zinda's readership grew from the initial 12 recipients to 28,000 readers from 64 countries with nearly a million hits per month. ${ }^{36}$

${ }^{35}$ Firas Jatou, e-mail personal communication dated Apri 2, 2005.

36 Wilfred Alkhas, e-mail personal communication dated April 5, 2005. 
In mid 1995, the first Church-based web site appeared as a family effort by the Issas of Australia. Corepiscopos Boutros Touma, his son Touma Issa and daughter Theodora Issa put together a web site on the Syrian Orthodox Church. Due to a lack of a proper web server, Touma Issa hosted the site on his personal Windows 3.1 desktop using special software called Windows httpd that allowed the computer to serve web pages. He had to keep the desktop turned on 24/7. The URL was on the Murdock University network (http://chempc25.murdoch.edu), then moved after two years to a proper web server on the University network (wwwstaff.murdoch.edu.au/ $\sim \mathrm{t}$-issa/syr/syr.htm). In 2005, the site was moved out of the university to a free geocities web server (http:// soca.cjb.net and http://syriac.cjb.net).

On September 5, 1995, Thomas Joseph became the first Indian Syriac Christian to produce a church web site. The site initially located at http://www.netadventure.com/ soc (now defunct) started as a web site for his parish, St. Mary's at Los Angeles. On May 16, 1996, it was expanded and named the Syrian Orthodox Resources (SOR) and went live at a web server at UCLA where Thomas was a graduate student. On May 1, 2000, the site was renamed 'Syriac Orthodox Resources' and moved to The Catholic University of America (http://sor.cua.edu) where it is currently hosted. SOR remains today one of the richest sites on the spiritual heritage of the Syriac Orthodox Church.

Also in 1995, a newsgroup called soc.culture.assyrian was proposed by Peter Jasim and became the first community discussion forum.

After 1996 the number of scholarly and community based sites exploded so that it became impossible to track them down. Whereas a web search for Syriac studies yielded only a few results back in 1994, today a Google search on the word "Syriac" yields 1.7 million pages (compare with a search done in 2005 which resulted in 300,000 pages). Google now gives suggestions based on what users search. The top search strings that users utilize which begin with Syriac are: Syriac Orthodox Church, Syriac Orthodox, Syriac Church, Syriac alphabet, Syriac Christianity, Syriac Bible, Syriac fonts, and Syriacus.

I shall conclude this section with two contributions by Beth Mardutho. In 1998, Beth Mardutho began publishing Hugoye: Journal of Syriac Studies. In addition to being the first and only peer-reviewed journal dedicated entirely to the Syriac heritage, the journal was totally electronic with free access online. Thomas Joseph assumed the position of Technical Editor and devised the templates necessary to publish the journal. Hugoye followed a tradition established by TC: A Journal of Biblical Textual Criticism, available at http://rosetta.reltech.org/TC/TC.html numbering logical paragraphs to be used as references instead of page numbers. Beth Mardutho planned from the outset to publish Hugoye in print as well, and while there have been delays, plans are now underway to accomplish this. Beth Mardutho also 
plans in the near future to add to its web site a collection of over 1,000 books, manuscripts and archival material in digital form. This will hopefully become an indispensable tool in our field.

\section{FUTURE CONSIDERATIONS}

[49] Syriac computing has gone a long way especially in the past two decades; however, there is a need for much more to be done.

An optical character recognition (OCR) system that can cope with the various Syriac scripts is a desideratum. It will help us scan hundreds of texts not as images, but as searchable texts. This will also open the way for texttagging projects along the lines of similar projects for Greek and Latin. The field is lucky to have William Clocksin ${ }^{37}$ who has been working in the past few years on such a system. It is hoped that soon a user-friendly application can be hosted online that will allow users to upload images of texts and download them in Unicode searchable and editable form.

Another desideratum is a general knowledge-base that embodies an encyclopedia in the traditional sense, but also would link to bibliographical and manuscript-catalog databases. To these one can add a book review database, and a colophon database. Imagine if in a simple search, one could find everything that was published on a Syriac author, a list of the author's works, the manuscripts containing those works and their colophons! The design of such a system is not too difficult and can be achieved in a very short period of time. What is time-consuming is populating the database. In the absence of funding, one may have to resort to a Wikipedia type encyclopedia where the users populate the data themselves.

If one is allowed to dream, one can add another desideratum: a linguistic database of the language that would include a computational lexicon and a natural language engine. The data model behind the computational lexicon needs to cover not only typical fields that are found in paper-lexica (variant orthographies, dialectical variants, historical spellings, collocations, idiomatic phrases, etc.), but also grammatical, morphological and phonological data that give flexibility for future applications. For instance, there has been hardly any system in previous lexical projects that encodes phonological information, and while most would cater to morphological paradigms, probably none marks things like transitiveness. Of equal importance are semantic and thesaurus-type information. These would not only allow the user to search the lexicon based on concepts (rather than mere roots, lexemes or word forms), but

${ }^{37}$ For an earlier report, see William Clocksin and Prem Fernando, 'Towards automatic transcription of Estrangelo script' in Hugoye 6 (2003) [http://www. bethmardutho.org/hugoye]. 
also would allow the building of semantic relations and hierarchies. ${ }^{38}$ Such a system would allow for writing applications to assist in the grammatical tagging of texts, and we might as well drop a spelling checker there.

Multi-media can also play a role in projects. One project that comes to mind is a comprehensive recording of the Beth Gazo melodies according to various traditions. Syriac Orthodox Resources and Beth Mardutho have already digitized the recordings of Patriarch Jacob III and a few others, but a larger enterprise is needed to create a comprehensive searchable database that makes use of audio and texts.

Each person probably has his or her own wish list. Would you like your iPod to display Syriac?

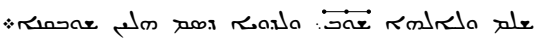

\section{BIBLIOGRAPHY}

Julie D. Allen et al. (eds), The Unicode Standard, Version 5.0 (2007).

P. Borbone, 'L'uso dell'elaboratore elettoronico per lo studio della Pešitța,' Henoch 9 (1987), pp. 55-96.

P. Borbone, 'Un programma per l'elaborazione di testi siriaci e un progetto di redazione di concordanze della peshitta,' in R. Lavenant (ed.), $V$ Symposium Syriacum 1988, Orientalia Christiana Analecta 236 (1990), pp. $439-50$.

P. Borbone and F. Mandracci, 'Another way to analyze Syriac texts, a simple powerful tool to draw up Syriac computer aided concordances,' in Proceedings of the Second International Colloquium, Bible and Computers: Methods Tools, Results, Travaux de Linguistique Quantitative 43 (1989), pp. 135-45.

British and Foreign Bible Society, The New Testament in Syriac (London: 1919 and subsequent editions).

William Clocksin and Prem Fernando, 'Towards automatic transcription of Estrangelo script' in Hugoye 6 (2003) [http://www.bethmardutho. org/hugoye].

J. F. Coakley, Typography of Syriac: A Historical Catalogue of Printing Type, 1537-1958 (Oak Knoll Press, 2006).

D. A. Cruse, Lexical Semantics (Cambridge: Cambridge University Press, 1986).

Yannis Haralambous, 'Sabra, a Syriac TEX System' in G. Kiraz (ed.), SyrCOM-95: Proceedings of the First International Forum on Syriac Computing (Cambridge: The Syriac Computing Institute, 1995).

George A. Kiraz, ri.eo The Syriac Electronic Data Research Archive (SEDRA) (leaflet), pp. 1-3.

George A. Kiraz, "Computers: Innovation and New Future to Syriac Studies." René Lavenant, S.J. (ed.), V Symposium Syriacum 1988. Orientalia Christiana Analecta 236, 1990, pp. 451-8.

38 D. A. Cruse, Lexical Semantics (Cambridge: Cambridge University Press, 1986). 
George A. Kiraz, 'Automatic Concordance Generation,' in René Lavenant (ed.), VI Symposium Syriacum 1992, Orientalia Christiana Analecta 247, pp. 461-475.

George A. Kiraz, A Computer-Generated Concordance to the Syriac New Testament, 6 vols. (Leiden: E. J. Brill, 1993).

George A. Kiraz, 'Automatic concordance generation of Syriac texts,' in R. Lavenant (ed.), VI Symposium Syriacum 1992, Orientalia Christiana Analecta 247 (1994), pp. 461-75.

George A. Kiraz, Lexical Tools to the Syriac New Testament (Sheffield: Sheffield Academic Press, 1994; Piscataway: Gorgias Press, 2002).

George A. Kiraz, Comparative Edition of the Syriac Gospels, Aligning the Sinaiticus, Curetonianus, Peshitta and Harklean Versions, 4 vols. (Brill, 1996; Gorgias Press, 2004).

George A. Kiraz, Computational Nonlinear Morphology: With Emphasis on Semitic Languages (Cambridge: Cambridge University Press, 2001).

George A. Kiraz and Daniel Ponsford, 'Automatic Compilation of Semitic Lexica,' in Proceedings of the $4^{\text {th }}$ International Conference and Exbibition on MultiLingual Computing (1994).

George A. Kiraz and Daniel Ponsford, 'The Arabic-Syriac/Syriac-Arabic Dictionary Project: Report II,' in G. Kiraz (ed.), SyrCOM-95: Proceedings of the First International Forum on Syriac Computing (1995).

Thomas Koonammakkal Kathanar, 'Malayalam Karshon' in The Harp 10 (1997):5964.

George A. Lamsa, The Holy Bible From Ancient Eastern Manuscripts, Containing the Old and New Testaments Translated from the Peshitta, The Authorized Bible of the Church of the East (Nashville: Holman Bible Publishers, 1933, 22 ${ }^{\text {nd }}$ printing 1981).

George M. Lamsa, New Testament Origin (Aramaic Bible Center, 1976).

Logos Research Systems, Scholar's Library Silver Editon: A professional-level library of texts and tools for serious Bible Study using Greek, Hebrew, and English resources, Logos Bible Software Series X (2004).

J. Lund (in collaboration with George A. Kiraz), The Old Syriac Gospel of the Distinct Evangelists, A Key-Word-In-Context Concordance, volumes 1-3 (Piscataway: Gorgias Press, 2004).

Paul Nelson, George Kiraz and Sargon Hasso, Proposal to encode Syriac in ISO/IEC 10646 (February 20, 1998), 46 pages. Independently, an earlier proposal was filed by Sargon Hasso and Peter Jasim in 1997.

The Peshitta Institute, The Old Testament Concordance According to the Peshitta Version, Part V Concordance (Leiden: E. J. Brill, 1997).

Raima Corporation, db_VISTA III ${ }^{\mathrm{TM}}$, Version 3.10 (Bellevue, WA: 1989).

Nicholas Sims-Williams and Michael Everson, Proposal to add six Syriac letters for Sogdian and Persian to the UCS (March 30, 2002).

Werner Strothmann, Konkordanz zum Syrischen Psalter (1976); Werner Strothmann, Konkordanz zur Syrischen Bible: Der Pentateuch (1986), Der Propheten (1984).

The Unicode Consortium, The Unicode Standard, Version 3.0 (2000).

The Way International, The Concordance to the Peshitta Version of the Aramaic New Testament (Ohio: American Christian Press, 1985).

The Way International, The Aramaic New Testament (Ohio: American Christian Press, 1983). 
The Way International Research Team, Aramaic-English Interlinear New Testament, vol. 1 Matthew-John 1988, vol. 2 Acts-Philemon 1988, vol. 3 HebrewsRevelation (American Christian Press, 1989).

The Way International, English Dictionary Supplement to the Concordance to the Peshitta Version of the Aramaic New Testament (American Christian Press, 1985).

M. Zumpe, Technische Aspekte der Göttingen Syrischen Konkordanz. (Deutsche Arbeitsgemeinschaft Vorderer Orient, September 2001). 
